\title{
Association of the Nrampl gene polymorphisms and clinical forms in patients with tuberculosis
}

\author{
Hanta $\mathrm{I}^{1}$, Tastemir-Korkmaz $\mathrm{D}^{2}$, Demirhan $\mathrm{O}^{3}$, Hanta $\mathrm{D}^{4}$, Kuleci $\mathrm{S}^{1}$, Seydaoglu $\mathrm{G}^{5}$ \\ Department of Chest Diseases, Faculty of Medicine, Cukurova University, Adana, Turkey. ihanta@cu.edu.tr
}

\begin{abstract}
Background: Recent studies have reported that Nramp1 polymorphisms might have an important role in the development of tuberculosis in various populations. In this study, we aimed to determine Nramp1 polymorphisms in our patients with tuberculosis population.

Methods: We enrolled 127 patients with active tuberculosis and 116 healthy adults with similar age and gender. Peripheral blood samples were taken for determining the Nramp1 polymorphisms. By using Polymerase Chain Reaction (PCR) - Restriction Fragment Length Polymorphisms (RFLP) technique, we evaluated the polymorphisms of Nramp1 at the regions of D543N and INT4.

Results: We found that the Nramp1 polymorphisms at the region of D543N (OR: $0.44,95 \% \mathrm{Cl}: 0.09-2.06$ for GA allele) were not a risk factor for tuberculosis. Furthermore, we could not able to detect Nramp1 polymorphism at the regions of INT4 (OR: $0.97,95 \% \mathrm{Cl}: 0.55-1.72$ for $\mathrm{GC}$ allele and OR: $0.90,95 \% \mathrm{Cl}$ : $0.21-3.77$ for CC allele). Conclusion: The findings of the present study do not support the hypothesis that Nramp1 at the regions of D543 and INT4 might play a role in influencing the growth of bacilli and progression of cavitary tuberculosis rather than susceptibility to $M$. tuberculosis infection. Future studies are needed to elucidate the role of Nramp1 variants in the pathogenesis of tuberculosis (Tab. 3, Ref. 29). Full Text in PDF www.elis.sk.

Key words: tuberculosis, pathogenesis, Nramp1 gene polymorphisms.
\end{abstract}

Tuberculosis (TB) is a major health problem throughout the world causing large number of deaths, more than that from any other single infectious disease. The global incidence of TB is rising, with 8.5-9.2 million new cases and 1.2-1.5 million deaths each year (1). Turkey is also a country with a moderate TB incidence. However, only $10 \%$ of those infected are estimated to progress to active TB disease. Susceptibility to TB is multifactorial. Host genetic factors are important determinants of susceptibility to TB (2). The doubly high risk of disease in identical twins compared with nonidentical twins indicates a host genetic component in susceptibility (3). It is likely that host susceptibility to TB is at least partly under polygenic control. The importance of host genetic factors on the susceptibility or resistance to TB has been emphasized by many researchers. Moreover, it was suggested by the recent description of Nramp1 susceptibility alleles in children with TB (4). Natural resistance-associated macrophage protein 1 (Nramp1), best characterized gene, is known to be associated with tuberculosis. Nramp1 protein is a transmembrane iron transporter

${ }^{1}$ Department of Chest Diseases, Faculty of Medicine, Çukurova University, Adana, Turkey, ${ }^{2}$ Vocational School of Health Services, Adiyaman University, Adiyaman, Turkey, ${ }^{3}$ Department of Medical Biology and Genetics, Faculty of Medicine, Çukurova University, Adana, Turkey, ${ }^{4}$ Deparment of Pediatry, Numune Education and Research Hospital, Adana, Turkey, and ${ }^{5}$ Department of Biostatistics, Faculty of Medicine, Çukurova University, Adana, Turkey

Address for correspondence: I. Hanta, MD, Department of Chest Diseases, Faculty of Medicine, Cukurova University, 01330 Balcali, Adana, Turkey. Acknowledgement: This study was supported by the Research Fund of Cukurova University Adana, Turkey. expressed mainly in phagocytes and located in the membrane of the phagolysome $(5,6)$. Although the function of Nrampl is not known in detail, one important function is probably to pump divalent cations $\left(\mathrm{Fe}^{2+}\right)$ across the phagosome membrane (7). This is interesting in relation to $\mathrm{TB}$, because the $\mathrm{Fe}^{2+}$ concentration might affect the mycobacterial growth in the phagosome (8). In a much larger study on tuberculosis in Gambia, West Africa, Bellamy et al (9), identified a clear association between variants of the Nrampl gene and susceptibility to this mycobacterial disease, though the mechanism is still elusive. Potential malfunction of these aspects may affect innate and adaptive immune responses to $M$. Tuberculosis infection (6). In some studies performed in different ethnical population, weak and/or strong evidence of linkage was found between Nramp1 and TB (10-18). Polymorphisms in the Nramp1 gene have also been found in a number of genetic studies to be risk factors for the development of TB among adult populations $(13-15,18)$. However, except for the study of a TB outbreak in a Canadian community (12), no distinction was made between primary and reactivation TB for the patients enrolled in these previous studies. Such a study design might miss or underestimate the genetic control mechanisms that differ in the development of primary and reactivation tuberculosis. Human case-control studies have suggested that polymorphisms in the human homologue Nramp1 modify the TB susceptibility in some subgroups of African and Asian populations $(9,19,20)$. Soborg et al (21) indicate that variant alleles in the Nrampl gene are associated with increased mycobacterial replication rather than susceptibility for TB and may thus confer an increased risk of severe disease. 
$657-660$

Here we searched for the possible association between the polymorphisms of Nrampl gene in Turkish TB population.

\section{Materials and methods}

\section{Patients}

The study involved 127 patients with active tuberculosis referred from Department of Chest Diseases, School of Medicine, Cukurova University, Adana-Turkey and 116 healthy adults with similar age and gender. Also, it was granted ethical approval by the local health committee and permission from all patients and controls. Peripheral blood samples were taken from study groups for determining the Nrampl gene polymorphisms. By using the methods of Polymerase Chain Reaction (PCR) - Restriction Fragment Length Polymorphisms (RFLP), we evaluated the polymorphisms of Nrampl gene at the regions of D543N and INT4. The patient group consisted of 100 males and 27 females. Their ages ranged from 18 to 79 years with a mean age of 36 years. The control group consisted of 97 males and 19 females (ranging from 18 to 78 years with a mean age of 38 years). Collective data were taken for each patient (age; risk factors: diabetes, smoking, immunosuppressive therapy; chest x-ray findings: cavitary, localised pneumonic lesion, multilobar infiltration, miliary, pleurisy; diagnostic tools: sputum and bronchoalveolar lavage smear, M.tuberculosis culture positivity, and histopathologic examination of pleural biopsy specimens). Tobacco consumption of these patients ranged from 10-80 packs per year and the average tobacco consumption was $35.35 \pm 22.33$ packs per year. It was also recorded that four patients had never used tobacco. None of the patients received chemotherapy or radiotherapy before the present analysis. The diagnostic criteria for patients were culture confirmation of TB (127 cases) or clear clinical criteria of disease. The disease manifestation was classified as pulmonary (51.3\%), extrapulmonary $(37.5 \%)$, and both pulmonary and extrapulmonary $(11.2 \%)$.

\section{Genotyping}

A 3-ml sample of blood was taken from all subjects and referred to Department of Medical Biology and Genetics, Faculty of Medicine, Cukurova University. Genomic DNA was isolated from $0.2 \mathrm{ml}$ of whole blood using QIAMP-DNA isolation kit (Qiagen). We selected two DNA polymorphisms in the Nramp1 gene (GenBank Accession no L32185): D543N and INT4, and identified proper primers for all two sites from literatures $(22,23)$. D543N site, a nonconservative single-base substitution at codon 543 causes a change from aspartic acid to asparagine, was amplified using sense primer (5'-GCATCTCCCCAATTCATGGT-3') and antisense primer (5'-AACTGTCCCACTCTATCCTG-3'). Product size was 240 or $244 \mathrm{bp}$. PCR cycle conditions were $95^{\circ} \mathrm{C}$ for $5 \mathrm{~min}$, followed by $94{ }^{\circ} \mathrm{C}$ for $30 \mathrm{~s}, 57^{\circ} \mathrm{C}$ for $30 \mathrm{~s}$, and $72{ }^{\circ} \mathrm{C}$ for $30 \mathrm{~s}(30$ cycles). The PCR mixture ( $25 \mu \mathrm{l})$ included 1XPCR Buffer, $2 \mathrm{mM}$ $\mathrm{MgCl}_{2}, 0.2 \mathrm{mM}$ dNTPs, 5 pmol primer, $100 \mathrm{ng}$ DNA, and $2 \mathrm{U}$ Taq Polimeraz (Fermantas). Similarly, INT4 (469+14G/C) was amplified using sense primer 5'-TCTCTGGCTGAAGGCTCTCC-3' and antisense primer 5'-TGTGCTATCAGTTGAGCCTC-3'. Product size was $624 \mathrm{bp}$. PCR cycle conditions were $95^{\circ} \mathrm{C}$ for $10 \mathrm{~min}$, followed by $94{ }^{\circ} \mathrm{C}$ for $30 \mathrm{~s}, 64^{\circ} \mathrm{C}$ for $30 \mathrm{~s}, 72^{\circ} \mathrm{C}$ for $30 \mathrm{~s}$ ( 30 cycles).
The PCR mixture ( $25 \mu \mathrm{l})$ included 1 XPCR Buffer, $1.5 \mathrm{mM} \mathrm{MgCl}_{2}$, $0.2 \mathrm{mM}$ dNTPs, 5 pmol primer, $100 \mathrm{ng}$ DNA sample and $2 \mathrm{U}$ Taq Polimeraz (Takara Taq ${ }^{\mathrm{TM}}$ Hot Start DNA Polimeraz, Takara Bio Inc.). The amplified DNA fragments surrounding the D543N and INT4 were incubated with $5 \mathrm{U}$ of the restriction enzymes AvalI (for D543N) and ApaI (for INT4) at $37^{\circ} \mathrm{C}$ for $2 \mathrm{~h}$, and restriction digests were evaluated using $10 \%$ polyacrilamid gels in $1 \mathrm{XTBE}$, and visualised by ethidium bromide staining. To determine the size of the banding patterns, pUC18/HaeIII marker were loaded together with the digested samples and then compared with it.

\section{Statistical analysis}

Comparisons of continuous variables were applied using the student $t$-test between groups. The categorical variables between the groups were analyzed by using the Chi square test or Fisher's exact test. The Odds Ratio (OR) and 95\% confidence interval $(95 \% \mathrm{CI})$ was calculated by using SPSS statistical software15.0 (SPSS Inc.). Results were expressed as mean \pm standard deviation, $\mathrm{n}(\%)$, OR and CI. The results were considered statistically significant if $\mathrm{p}<0.05$.

\section{Results}

We analysed a total of 127 patients with tuberculosis for polymorphic changes in the D543N and INT4 loci of the Nrampl gene, because these two loci were repeatedly evaluated by different laboratories for genetic variation and susceptibility to tuberculosis. The characteristics of our study groups are summarized in Table 1. There were no differences between study groups according to age and gender. While the most important risk factor is diabetes mellitus, the most frequent radiological lesion is cavitary lesion in our study group. The homozygous $\mathrm{G} / \mathrm{G}$ variant in the D543N locus was

Tab. 1. Characteristics of patients with tuberculosis and healthy controls.

\begin{tabular}{|c|c|c|c|}
\hline Features & $\begin{array}{l}\text { Patients with TB } \\
(\mathrm{n}=127) \\
\text { Number of } \\
\text { patients }(\%) \\
\end{array}$ & $\begin{array}{l}\text { Healthy controls } \\
\qquad(\mathrm{n}=116) \\
\text { Number of } \\
\text { patients }(\%]\end{array}$ & $\begin{array}{c}\mathrm{p} \\
\text { value }\end{array}$ \\
\hline Male & $100(78.7 \%)$ & $97(83.6 \%)$ & 0.3 \\
\hline Female & $27(21.3 \%)$ & $19(16.4 \%)$ & \\
\hline Age, years $(\text { mean } \pm S D)^{*}$ & $36(18-79)$ & $38(18-78)$ & 0.4 \\
\hline $\begin{array}{l}\text { Risk factors; } \\
\text { Diabetes } \\
\text { Smoking } \\
\text { Immunosuppressive therapy }\end{array}$ & $\begin{array}{c}23(18.1 \%) \\
21(16.5 \%) \\
1(0.8 \%)\end{array}$ & - & \\
\hline $\begin{array}{l}\text { Chest } \mathrm{x} \text { ray findings; } \\
\text { Cavitary } \\
\text { Localised pneumonic lesion } \\
\text { Multilobar infiltration } \\
\text { Miliary } \\
\text { Pleurisy }\end{array}$ & $\begin{array}{c}67(52.8 \%) \\
26(20.5 \%) \\
29(22.8 \%) \\
1(0.8 \%) \\
4(3.1 \%)\end{array}$ & - & \\
\hline $\begin{array}{l}\text { Diagnostic tools; } \\
\text { Sputum smear } \\
\text { Culture positivity } \\
\text { Bronchoalveolar lavage } \\
\text { Pleural biopsy }\end{array}$ & $\begin{array}{c}116(91.3 \%) \\
5(3.9 \%) \\
3(2.4 \%) \\
3(2.4 \%)\end{array}$ & - & \\
\hline
\end{tabular}


Tab. 2. Nramp1 gene polymorphisms and tuberculous.

\begin{tabular}{lccc}
\hline Polymorphisms & $\begin{array}{c}\text { Patients with TB } \\
(\mathrm{n}=127) \\
\text { Number of } \\
\text { patients }(\%)\end{array}$ & $\begin{array}{c}\text { Healthy controls } \\
(\mathrm{n}=116) \\
\text { Number of } \\
\text { patients }(\%)\end{array}$ & $\begin{array}{c}\text { Odds ratio } \\
\left(95 \% \mathrm{CI}^{*}\right) \\
\mathrm{p} \text { value }\end{array}$ \\
\hline $\mathrm{D} 543 \mathrm{~N}$ & & & \\
$\mathrm{G} / \mathrm{G}$ & $124(97.6 \%)$ & $110(94.8 \%)$ & 1 \\
$\mathrm{G} / \mathrm{A}$ & $3(2.4 \%)$ & $6(5.2 \%)$ & $0.44(0.09-2.06) 0.2$ \\
$\mathrm{~A} / \mathrm{A}$ & - & - & \\
$\mathrm{INT} 4$ & & & 1 \\
$\mathrm{G} / \mathrm{G}$ & $80(63 \%)$ & $72(62 \%)$ & $0.97(0,55-1,72) 0.9$ \\
$\mathrm{G} / \mathrm{C}$ & $42(33 \%)$ & $39(33.6 \%)$ & $0.9(0.21-3.77) 0.8$ \\
$\mathrm{C} / \mathrm{C}$ & $5(4 \%)$ & $5(4.3 \%)$ & $0.90(0)$
\end{tabular}

detected in $124(97.6 \%)$ patients with tuberculosis and in $110(94.8$ $\%$ ) control subjects who were matched to patients on the basis of ethnicity. The heterozygous G/A variants were found in only 3 (2.4 $\%)$ patients and 6 (5.2\%) control subjects (Tab. 2). Similarly, the $\mathrm{G} / \mathrm{C}$ variant in the INT4 locus was identified in $42(33 \%)$ patients and in 39 (33.6\%) control subjects, whereas homozygous $\mathrm{G} / \mathrm{G}$ and $\mathrm{C} / \mathrm{C}$ variants were detected in $80(63 \%)$ and $5(4 \%)$ patients and $72(62 \%)$ and $5(4.3 \%)$ control subjects, respectively (Tab. 2). The homozygous $\mathrm{G} / \mathrm{G}$ and $\mathrm{C} / \mathrm{C}$ variants were identified in INT4 loci of $44(34.6 \%)$ and $2(1.6 \%)$ patients with cavitary lesion, and in 36 $(28.3 \%)$ and $3(2.4 \%)$ patients with no cavitary lesion, respectively, whereas heterozygous $\mathrm{G} / \mathrm{C}$ variant was exhibited in INT4 loci of 21 (16.4\%) patients with cavitary lesion and $21(18.7 \%)$ patients with no cavitary lesion, respectively (Tab. 3). Statistical analyses indicated that these variants at the 2 loci were not significantly correlated with cavitary tuberculosis $(p=0.2$ and $p=0.8$, for variants at the INT4 and D543N loci, respectively), compared with control subjects. Similarly, no association was observed between cavitary and noncavitary tuberculous lesions. Thus, the data suggested that allelic variants in INT4 and D543N loci of Nramp1 gene were not associated with severe forms of cavitary tuberculosis in Turkish patients.

\section{Discussion}

Tuberculosis remains the single largest infectious disease causing high mortality in humans. Approximately 8.5-9.2 million people are infected with this pathogen every year (1). Turkey is a country with a moderate TB incidence, reaching 33.7 per 100,000 population in 1999 and 26.3 per 100,000 in $2000(24,25)$. The evidence suggests that genetic factors may be important determinants of increased susceptibility to progressive disease development (26). Numerous host genes are likely to be involved in this process. By using a variety of study methods, substantial progress has already been made in advancing our understanding of genetic susceptibility to TB. The initial study by Bellamy et al. (9) demonstrated that 4 Nrampl gene variants, including those in the INT4 and D543N loci, were each significantly associated with susceptibility to TB in West Africa. Case-control studies have also indicated that polymorphisms of human Nramp1 modify host susceptibility to $M$. Tuberculosis among several major ethnic populations, including Asians (19). The human Nrampl gene has several polymorphisms
Tab. 3. Cavitary lesions and Nramp1 gene polymorphisms.

\begin{tabular}{lccc}
\hline Polymorphisms & $\begin{array}{c}\text { Cavitary lesion } \\
(\mathrm{n}=67) \\
\text { Number of } \\
\text { patients }(\%)\end{array}$ & $\begin{array}{c}\text { No cavitary lesion } \\
(\mathrm{n}=60) \\
\text { Number of } \\
\text { patients }(\%)\end{array}$ & $\begin{array}{c}\text { Odds ratio } \\
(95 \% \mathrm{CI}) \\
\mathrm{p} \text { value }\end{array}$ \\
\hline $\mathrm{D} 543 \mathrm{~N}$ & & & \\
$\mathrm{G} / \mathrm{G}$ & $66(52 \%)$ & $58(45.7 \%)$ & 1 \\
$\mathrm{G} / \mathrm{A}$ & $1(0.78 \%)$ & $2(1.6 \%)$ & $0.43(0.03-4.97) 0.4$ \\
$\mathrm{INT} 4$ & & & 1 \\
$\mathrm{G} / \mathrm{G}$ & $44(34.6 \%)$ & $36(28.3 \%)$ & $0.82(0.39-1.72) 0.5$ \\
$\mathrm{G} / \mathrm{C}$ & $21(16.5 \%)$ & $21(16.5 \%)$ & $0.54(0.08-3.44) 0.5$ \\
$\mathrm{C} / \mathrm{C}$ & $2(1.6 \%)$ & $3(2.4 \%)$ & \\
$* \mathrm{CI}=$ confidence interval & &
\end{tabular}

(27). However, Nramp1-associated susceptibility to tuberculosis could not be confirmed by other studies involving patients living in Morocco, Japan, or Brazil $(10,19,28)$. A study carried out in Taiwanese population revealed no association of Nrampl gene variants with the susceptibility to TB (29). Also in Turkey, Solgun et al (17) had the same results in Turkish pediatric patients with tuberculosis. Linkage between TB and the Nrampl locus has been shown in a large Canadian pedigree (12), but linkage was not seen in Brazilian, West African or South African populations (10, 11). One of the possible explanations for this inconsistency between these studies is that the genetic diversity among ethnicities could confer various genetic mechanisms underlying the TB susceptibility on the ethnic populations studied. By contrast to what has been suggested for other ethnic/racial groups, our studies on Nramp1 gene polymorphisms (D543N G/G, G/A, A/A and INT4 G/G, G/C, $\mathrm{C} / \mathrm{C}$ ) in TB patients revealed no association with the susceptibility to cavitary TB in Turkish population (Tab. 1). A number of factors may be responsible for the discrepant results reported by different studies. Ethnic or racial backgrounds can certainly introduce some variation (27). In fact, the INT4 variant allele can be found in nearly $50 \%$ of white Europeans, whereas the frequency of this allele is as low as nearly $20 \%$ in the Chinese population $(21,23)$. Also, Stragas et al (18) reported that INT4 - CC allele was a risk factor for TB in Greeks. In China, D543N locus in Nramp1 gene was recorded as a risk factor in ethnic Han Chinese children (14). In another study, variant genotypes at 3' UTR locus in Nramp1 gene were associated with pediatric tuberculosis in Chinese patients (15). Severe forms of cavitary TB were defined as the presence of cavitary lesion on radiographs, because these clinical features represent the pathological consequences of high-level replicating or destructive M. tuberculosis infection. The severity of cases of tuberculosis in the West African study may help to explain, in part, why Nramp1associated susceptibility to TB can be seen in West African patients but not in clinically heterogeneous patients from Denmark, Brazil, or Asian countries $(21,23,28)$. The data obtained from the patients with advanced TB indeed implicate Nrampl polymorphisms as possibly being associated with severe forms of pulmonary tuberculosis as well as in West Africa. The studies from Japan, Korea, and Denmark also support the presumption that Nrampl variants are associated with the development of severe forms of pulmonary TB (19-21). The frequency of Nrampl variants was higher among patients in Denmark who had microscopy-positive TB (21). The 
reason that no correlation between Nrampl variants and cavitary TB was noted in the Danish study might be attributed to the fact that although patients with cavitary TB were compared with patients without cavitary TB, they were not compared with the ethnically matched, healthy control subjects in the genetic study (23). The role of Nrampl in human resistance to TB is still ambiguous. The results from our study indicate that variations of Nrampl polymorphism at the region of D543 and INT4 were not a risk factor for TB infection among our TB patients in our region. Future studies are needed to elucidate the role of Nrampl variants in the pathogenesis of TB. There is still much work to be done as many more tuberculosis susceptibility genes are likely to be identified.

\section{References}

1. World Health Organization (WHO). Global Tuberculosis Control, 2011.

2. Casanova JL, Abel L. Genetic dissection of immunity to mycobacteria: the human model. Annu Rev Immunol 2002; 20: 581-620.

3. Comstock GW. Tuberculosis in twins: a re-analysis of the Prophit survey. Am Rev Resp Dis 1978; 117: 621-624.

4. Malik S, Abel L, Tooker H, Poon A, Simkin L, Girard M, Adams GJ, Starke JR, Smith KC, Graviss EA, Musser JM, Schurr E. Alleles of the Nrampl gene are risk factors for pediatric TB disease. Proc Natl Acad Sci USA 2005; 102: 12 183-12 188.

5. Malo D, Vogan K, Vidal S, Hu J, Cellier M, Schurr E, Fuks A, Bumstead N, Morgan K, Gros P. Haplotype mapping and sequence analysis of the mouse Nrampl gene predict susceptibility to infection with intracellular parasites. Genomics 1994; 23: 51-61.

6. Gruenheid S, Pinner E, Desjardins M, Gros P. Natural resistance to infection with intracellular pathogens: the Nrampl protein is recruited to the membrane of the phagosome. J Exp Med 1997; 185: 717-30.

7. Agranoff D, Monahan IM, Mangan JA, Butcher PD, Krishna S. Mycobacterium tuberculosis expresses a novel $\mathrm{pH}$-dependent divalent cation transporter belonging to the Nramp family. J Exp Med 1999; 190: 717-724.

8. Agranoff D, Krishna S. Metal ion homeostasis and intracellular parasitism. Mol Microbiol 1998; 28: 403-412.

9. Bellamy R, Ruwende C, Corrah T, McAdam KP, Whittle HC, Hill AV. Variations in the NRAMP1 gene and susceptibility to tuberculosis in West Africans. N Engl J Med 1998; 338: 640-644.

10. Shaw MA, Collins A, Peacock CS, Miller EN, Black GF, Sibthorpe D, Lins-Lainson Z, Shaw JJ, Ramos F, Silveira F, Blackwell JM. Evidence that genetic susceptibility to Mycobacterium tuberculosis in a Brazilian population is under oligogenic control: linkage study of the candidate genes NRAMP1 and TNFA. Tuber Lung Dis 1997; 78: 35-45.

11. Bellamy R, Beyers N, McAdam KP, Ruwende C, Gie R, Samaai P, Bester D, Meyer M, Corrah T, Collin M, Camidge DR, Wilkinson D, Hoal-Van Helden E, Whittle HC, Amos W, van Helden P, Hill AV. Genetic susceptibility to tuberculosis in Africans: a genome-wide scan. Proc Natl Acad Sci USA 2000; 97: 8005-8009.

12. Greenwood CM, Fujiwara TM, Boothroyd LJ, Miller MA, Frappier D, Fanning EA, Schurr E, Morgan K. Linkage of tuberculosis to chromosome 2q35 loci, including $N R A M P 1$, in a large aboriginal Canadian family. Am J Hum Genet 2000; 67: 405-416.

13. Hoal EG, Lewis LA, Jamieson SE, Tanzer F, Rossouw M, Victor T, Hillerman R, Beyers N, Blackwell JM, Van Helden PD. SLC11A1 (NRAMP1) but not SLC11A2 (NRAMP2) polymorphisms are associated with susceptibility to tuberculosis in a high-incidence community in South Africa. Int J Tuberc Lung Dis 2004; 8: 1464-1471.
14. Jin J, Sun L, Jiao WW, Zhao SY, Li HM, Guan XL, Jiao AX, Chi W, Jiang ZF, Shen AD. Association of NRAMP1 gene polymorphisms with the susceptibility to tuberculosis in ethnic Han Chinese children. Zhongguo Dang Dai Er Ke Za Zhi 2009; 11 (4): 283-287.

15. Jin J, Sun L, Jiao W, Zhao S, Li H, Guan X, Jiao A, Jiang Z, Shen A. SLC11A1 (Formerly NRAMP1) gene polymorphisms associated with pediatric tuberculosis in China. Clin Infect Dis 2009; 48 (6): 733-738.

16. Hatta M, Ratnawati, Tanaka M, Ito J, Shirakawa T, Kawabata M. NRAMP1/SLC11A1 gene polymorphisms and host susceptibility to Mycobacterium tuberculosis and M. leprae in South Sulawesi, Indonesia. Southeast Asian J Trop Med Public Health 2010; 41 (2): 386--394.

17. Solğun HA, Taştemir D, Aksaray N, Inan I, Demirhan O. Polymorphisms in NRAMP1 and MBL2 genes and their relations with tuberculosis in Turkish children. Tuberk Toraks 2011; 59 (1): 48-53.

18. Stragas MK, Papaetis GS, Orphanidou D, Kostopoulos C, Syriou S, Reczko M, Drakoulis N. Polymorphisms of the NRAMP1 gene: distribution and susceptibility to the development of pulmonary tuberculosis in the Greek population. Med Sci Monit 2011; 17 (1): 1-6.

19. Gao PS, Fujishima S, Mao XQ, Remus N, Kanda M, Enomoto T, Dake Y, Bottini N, Tabuchi M, Hasegawa N, Yamaguchi K, Tiemessen C, Hopkin JM, Shirakawa T, Kishi F. Genetic variants of NRAMP1 and active tuberculosis in Japanese populations. International Tuberculosis Genetics Team. Clin Genet 2000; 58: 74-76.

20. Ryu S, Park YK, Bai GH, Kim SJ, Park SN, Kang S. 3'UTR polymorphisms in the NRAMP1 gene are associated with susceptibility to tuberculosis in Koreans. Int J Tuberc Lung Dis 2000; 4: 577-580.

21. Soborg C, Andersen AB, Madsen HO, Kok-Jensen A, Skinhoj P, Garred P. Natural resistance-associated macrophage protein 1 polymorphisms are associated with microscopy-positive tuberculosis. J Infect Dis 2002; 186: 517-521.

22. Abe T, Linuma Y, Ando M, Yokoyama T, Yamamoto T, Nakashima K, Takagi N, Baba H, Hasegawa Y, Shimokata K. NRAMP1 polymorphisms, susceptibility and clinical features of tuberculosis. J Infect 2003; 46: 215-20.

23. Zhang W, Shao L, Weng X, Hu Z, Jin A, Chen S, Pang M, Chen ZW. Variants of the natural resistance-associated macrophage protein 1 gene (NRAMP1) are associated with severe forms of pulmonary tuberculosis. Clin Infect Dis 2005; 40: 1232-1236.

24. Ozkara S, Kilicaslan Z, Ozturk F, Seymenoglu, Erdogan AR, Tellioglu C, Koşan AA, Kaya B, Koçoglu F, Kibaroglu E. Bölge verileriyle Turkiye'de tuberkuloz. Toraks Dergisi 2002; 3: 178-187.

25. Cuhadaroglu C, Erelel M, Tabak L, Kilicaslan Z. Increased risk of tuberculosis in health care workers: a retrospective survey at a teaching hospital in Istanbul, Turkey. BMC Infect Dis 2002; 2: 14.

26. Casanova JL, Abel L. Genetic dissection of immunity to mycobacteria: the human model. Annu Rev Immunol 2002; 20: 581-620.

27. Dupuis S, Dargemont C, Fieschi C, Thomassin N, Rosenzweig S, Harris J, Holland SM, Schreiber RD, Casanova JL. Impairment of mycobacterial but not viral immunity by a germline human STAT1 mutation. Science 2001; 293: 300-303.

28. El Baghdadi J, Remus N, Benslimane A, El Annaz H, Chentoufi M, Abel L, Schurr E. Variants of the human NRAMP1 gene and susceptibility to tuberculosis in Morocco. Int J Tuberc Lung Dis 2003; 7: 599-602.

29. Liaw YS, Tsai-Wu JJ, Wu CH, Hung CC, Lee CN, Yang PC, Luh KT, Kuo SH. Variations in the NRAMPI gene and susceptibility of tuberculosis in Taiwanese. Int J Tuberc Lung Dis 2002; 6: 454-460.

Received May 20, 2011. Accepted November 30, 2012. 